August 2012

\title{
State-Induced Famine and Penal Starvation in North Korea
}

Rhoda E. Howard-Hassmann

Follow this and additional works at: https://digitalcommons.usf.edu/gsp

\section{Recommended Citation}

Howard-Hassmann, Rhoda E. (2012) "State-Induced Famine and Penal Starvation in North Korea," Genocide Studies and Prevention: An International Journal: Vol. 7: Iss. 2: Article 3.

DOI: $10.3138 /$ gsp.7.2/3.147

Available at: https://digitalcommons.usf.edu/gsp/vol7/iss2/3

This Articles is brought to you for free and open access by the Open Access Journals at Digital Commons @ University of South Florida. It has been accepted for inclusion in Genocide Studies and Prevention: An International Journal by an authorized editor of Digital Commons @ University of South Florida. For more information, please contact digitalcommons@usf.edu. 


\section{State-Induced Famine and Penal Starvation in North Korea}

\section{Rhoda E. Howard-Hassmann \\ Canada Research Chair in International Human Rights}

This article discusses North Korea as a case of state-induced famine, or faminogenesis. A famine from 1994 to 2000 killed 3-5\% of North Korea's population, and mass hunger reappeared in 20102012, despite reforms meant to address the shortage of food. In addition, a prison population of about 200,000 people is systematically deprived of food; this might be considered penal starvation. There seems little recourse under international law to punish the perpetrators of state-induced famine and penal starvation. State-induced famine does, however, fit some of the criteria of genocide in the United Nations Convention against Genocide, and could also be considered a crime against humanity under the Rome Statute of the International Criminal Court. There would seem, then, to have been a case for referral of North Korea's recently deceased leader, Kim Jong Il, to the International Criminal Court, and it is still a case for referral of Kim's successors. However, strategic concerns about North Korea's nuclear weapons outweigh humanitarian concerns about North Korea's citizens.

Key words: North Korea, state-induced famine, faminogenesis, penal starvation

\section{Introduction}

Scholars of genocide know that it is not unusual for governments to kill their own citizens, but two ways that states do this have remained relatively unstudied. The first method is state-induced famine - that is, state policies that create famine. The second is penal starvation-state policies to starve prisoners to death.

David Marcus coined the term faminogenesis to describe public policies that generate famine, using Amartya Sen's definition of famine as a "particularly virulent manifestation of [starvation] causing widespread death." 1 Marcus presents a typology of four levels of faminogenic behavior: intentional famine (deliberately using famine as means of extermination), reckless famine (continuing policies despite evidence of famine), famine by indifference (turning a blind eye to mass hunger), and famine by incompetence. ${ }^{2} \mathrm{He}$ also recommends that intentional and reckless faminogenesis be specifically prohibited by international law. I add to Marcus's analysis my own recommendation that penal starvation also be specifically prohibited by international law, perhaps as a subcategory of faminogenesis. I define penal starvation as a state's deliberate policy to subject prisoners in penal institutions and camps to starvation rations.

I use the term state-induced famine interchangeably with faminogenesis to clarify that faminogenesis is often a state activity. The history of the twentieth century reveals several major cases in which communist states caused citizens to starve. Among those citizens were the approximately 3.3 million ethnic Ukrainians who starved to death in the Soviet Union in 1932-1933; $;^{3}$ the 45 million people who starved during Mao TseTung's "Great Leap Forward" from 1958 to $1962 ;^{4}$ and the hundreds of thousands who starved to death in Cambodia under the Khmer Rouge, 1975-1979. Similarly, both 
communist and fascist regimes used penal starvation as a tool of punishment and extermination. Under Nazi rule, Jews in ghettoes, Soviet prisoners of war, ${ }^{5}$ and all inmates of concentration camps faced starvation. Under communism, prisoners in the Soviet gulag $^{6}$ as well as the Chinese laogai (prison camp complex) ${ }^{7}$ were also starved to death. One might wish to think that state-induced famine and penal starvation disappeared with the defeat of Nazism and the end of both Soviet and Chinese communism, but there are still countries where these practices exist-for example, North Korea (formally named the Democratic People's Republic of Korea). North Korea is an example of reckless and possibly intentional faminogenesis.

Examination of North Korea raises the question of whether intentional and reckless faminogenesis is or should be considered an aspect of the crime of genocide. Knowledge of the general human rights situation helps to evaluate whether a famine is intentional or reckless. If a regime denies all human rights, it cannot be deemed less than reckless in its creation of a famine. Famines do not occur, contends Sen, in countries with functioning multiparty democracies. ${ }^{8}$ This is because when citizens can exercise their democratic rights, they can protest against government policies that undermine their access to food and threaten to vote the government out of office. No such recourse is possible in totalitarian dictatorships such as North Korea.

This article begins with a brief historical background, followed by sections explaining the occurrence of famine in North Korea in the mid-1990s and 2010-2012, and discussing the legal basis for considering North Korea's food policies to be at minimum reckless, possibly intentional, faminogenesis. Following this is a section describing penal starvation and its victims. The article continues with discussion of what could have been done under international law before the December 2011 death of Kim Jong Il-North Korea's leader since 1994-to punish the regime for its use of famine and penal starvation. At best, I contend, Kim Jong Il was guilty of reckless faminogenesis and should have been prosecuted accordingly, had a law prohibiting reckless faminogenesis existed. In the absence of such a law, Kim should have been prosecuted for the many crimes again humanity-and possibly crimes of genocide-he had committed. Should the leaders who took over after Kim Jong Il's death continue his policies, they will also become candidates for such prosecution. However, as the final section explains, the international community's strategic and security interests in North Korea render it unlikely that the rulers of the country will be tried for any of these crimes.

Before continuing, a note is necessary on sources. This article relies in part on news reports, reports from international human rights non-governmental organizations, and books written by reporters and activists. These sources, in turn, rely heavily on interviews with North Korean refugees in South Korea and northern China; interviews in China are clandestine. It is almost impossible for foreigners to enter North Korea and those who do enter are very carefully watched. Nevertheless, the testimony that the various researchers have accrued over the years, especially since large numbers of people started to enter China illegally during the famine of the mid-1990s, is remarkably consistent and can be considered reliable. As of 2001, 2,300 refugee accounts existed; ${ }^{9}$ by 2011, there were many more. These are not sensationalist accounts; researchers are very careful to cross-check them when they can and, if possible, to conduct methodologically sound surveys of refugees. ${ }^{10}$ Taken as a whole and checked against other sources, refugees' accounts can be considered reasonably reliable. 


\section{Historical Background}

North Korea, a state severely isolated and cut off from the international community, is a creation of the Cold War. From 1910 to 1945, the Korean Peninsula was colonized by the Japanese. At the end of World War II, the Americans and Soviets agreed that Korea would be split at the 38th parallel, a line arbitrarily chosen as it roughly divided this ancient kingdom into two equal parts. Kim Il Sung, allegedly a heroic guerilla leader against the Japanese in Manchuria, ${ }^{11}$ was chosen by the Soviet Union to lead the North. In 1950, anticipating an easy victory, he attacked the South. The United Nations and the United States came to the defense of the South, leading newly Communist China to enter the war on the side of the North. An extremely brutal, three-year war ensued in which hundreds of thousands died, many from American bombs and napalm. ${ }^{12}$ North Korea is estimated to have suffered 300,000 military and 400,000 civilian deaths. ${ }^{13}$ In 1953, the two parties signed a truce and retreated to their respective sides of the 38th parallel. There is no peace treaty, and the two Koreas are still technically at war, leaving a heavily defended demilitarized zone between the two states.

North Korea's official ideology, introduced in 1970, is called Juche, comprising "self-control, independence, and self-sufficiency"14-in a word, self-reliance. The regime also perpetuates a mythology that its hereditary rulers represent "the will of both heaven and earth." 15 Kim Il Sung died in 1994 and was succeeded by his son Kim Jong Il, who ruled North Korea until his death; he, in turn, was succeeded by his own son, Kim Jong Un. While Kim Jong Il lived a life of luxury, enjoying Western movies, Western food cooked by imported chefs, and "entertainment women," 16 the overwhelming majority of the population lived on the edge of starvation. The official organ controlling the state is the Korean Workers' Party, ${ }^{17}$ supplemented by an extremely large military of approximately 1.1 million people out of an estimated population of 24.5 million. ${ }^{18}$

In the 1950s and 1960s, North Korea was more prosperous than its southern neighbor. ${ }^{19}$ In part, this was because it had inherited most of the industrial capacity and infrastructure created under Japanese rule; ${ }^{20}$ in part it was because the Soviet Union heavily subsidized its economy. ${ }^{21}$ When the Soviet Union de-Stalinized in the 1950s, North Korea turned to China for infrastructure, energy, and food support. Food shortages occurred in 1945-1946 (just after WWII), 1954-1955 (just after the Korean War), and 1969-1974, ${ }^{22}$ and food rations began to decline steadily from about $1970 .{ }^{23}$ Moreover, industry and infrastructure quickly declined as a result of inadequate maintenance, poor management, lack of spare parts, and lack of an external market for the shoddy goods that the factories produced. ${ }^{24}$

Problems in food production were caused in large part by highly inefficient, collectivized agriculture. Immediately after World War II, the government seized all land belonging to Japanese colonialists and Korean landlords and redistributed it to peasants. The initial redistribution was unsuccessful and food production fell. The government then collectivized all land in the $1950 \mathrm{~s},{ }^{25}$ first in cooperative farms and then in state farms. Above a certain minimum left for farmers' own consumption, the entire harvest had to be turned over to the state, which distributed it to citizens through the Public Distribution System (PDS) adopted in 1950. Outside the collectivized farms, only very tiny "micro-farms" on which citizens could cultivate fruits and vegetables and keep small animals, poultry, and bees for their personal consumption or for periodic, legal farmers' markets were allowed. ${ }^{26}$ 
About $62 \%$ of the people, mainly urban, were dependent on the PDS for all their food. The PDS distributed food according to a scale that privileged some categoriesespecially members of the ruling Korean Workers' Party and the military, and heavy industry workers. ${ }^{27}$ Even with the PDS system in place, however, the country relied on food aid from its Communist allies - the Soviet Union and China-as early as the 1980 s, as its own production of food substantially declined. ${ }^{28}$ Thus, North Korea's collectivized system of food production, its refusal to allow almost any private production of food, its prohibition of food markets, and its reliance on food rationing all set the stage for the famines of the 1990s and 2000s.

\section{Famine}

In the early 1990s, the World Food Programme (WFP) described the food situation in North Korea as a "famine in slow motion." ${ }^{29}$ By the mid-1990s, it was experiencing a major famine. While many refugee, newspaper, and other reports cited figures of up to 3 million out of a then population of 23 million as having died between 1994 and $2000,{ }^{30}$ scholarly accounts present a lower figure of about 600,000 to 1 million dead. ${ }^{31}$ A South Korean scholar using several types of demographic and statistical data concluded that between 580,000 and 1.1 million people lost their lives during the famine of $1994-2000$, or $3-5 \%$ of the population. ${ }^{32}$

North Korea attributed the famine to natural disasters, citing poor harvests and flooding in 1995. But these "natural" disasters were in large part a consequence of poor decisions by the central government in the 1980s about agricultural policies, which exacerbated the earlier food shortages caused by collectivized food production and distribution. During the 1980s, the government ordered continuous cropping and overuse of chemical fertilizers, which eroded soil quality; there was also much soil erosion and deforestation as hills were denuded of trees to provide more land for cultivation. ${ }^{33}$ When the floods came, terraced hillsides simply collapsed. By this point there was very little agricultural machinery or fuel; much cultivation was by hand.

This extremely poor agricultural policy was exacerbated when, in the early 1990s, both Russia and China cut their food and fuel aid to North Korea. ${ }^{34}$ Russia, the successor state to the Soviet Union, had no interest in subsidizing Communist states abroad. Chinese exports of maize to North Korea declined by 80\% from 1993 to 1994, in part because of a poor harvest in China itself and in part as punishment to North Korea for having opened up diplomatic relations with Taiwan. ${ }^{35}$ Both Russia and China informed North Korea that it would have to start paying market prices in hard currency for their exports. ${ }^{36}$

The regime responded by describing the famine as an "Arduous March." ${ }^{37}$ Adopting a disingenuous approach to the famine's causes, Kim Jong Il first urged upon his subjects the virtues of eating only two meals a day, ${ }^{38}$ then one, while in the meantime attributing the famine to an imperialist blockade against North Korea. ${ }^{39}$ At the same time, the regime reduced farm families' grain rations by $35 \%$, far below subsistence level. ${ }^{40} \mathrm{Ra}$ tions under the PDS also appeared to have been completely cut off to the northeast in 1994. ${ }^{41}$ Nevertheless, privileged groups-especially members of the government, the military, and the Korean Worker's Party-continued to receive rations. ${ }^{42}$

Reports on the famine, many by refugees, are heartbreaking. A refugee doctor described wasted (emaciated) children whose desperate mothers had fed them weeds and wild grasses. Unable to digest this food, children appeared in the doctor's underequipped North Korean hospital with severe medical complications, or simply with a 
vague malaise that preceded their deaths; babies died from lack of mother's milk. ${ }^{43}$ Often parents and grandparents denied themselves food so that children could eat; ${ }^{44}$ sometimes entire families killed themselves. ${ }^{45}$ Married women prostituted themselves in order to obtain money to buy food for their children. ${ }^{46}$ Homeless children were reputed to be cannibalized; ${ }^{47}$ one refugee reported witnessing the public execution of a 28 -yearold man accused of eating a four-year-old child; ${ }^{48}$ and the WFP requested the right to inspect farmers' markets where it was reported that "special meat" on offer was actually human flesh. ${ }^{49}$ Ironically, in this devastated land, the very children dying of starvation were taught a song about how they had "nothing to envy" from the rest of the world. ${ }^{50}$

In 1998, a survey by the Food and Agriculture Organization (FAO),WFP, and the European Union (EU) found that $60 \%$ of North Korean children were stunted and $50 \%$ malnourished. ${ }^{51}$ A survey conducted by the UN and EU in 2002 found that the average North Korean, 7-year-old boy was 20 centimeters shorter and 10 kilograms lighter than his counterpart in South Korea. ${ }^{52}$ Indeed, the height requirement for entry into the North Korean military was reduced because so many military-age men were stunted. ${ }^{53}$ Once the actual famine ended around 2000 as a result of better weather, international food aid, and some policy reforms, a "chronic food emergency" nevertheless ensued well into the first decade of the twenty-first century. ${ }^{54}$

After the worst of the famine in the 1990s, the government introduced some reforms in food production and distribution. As early as 1987, it had decided to permit industrial workers to cultivate small plots of land at their under-producing factories and to permit farmers to expand their personal plots and trade in illegal-though tolerated-farmers' markets. ${ }^{55}$ The factories were given some autonomy from state control and were granted permission to trade manufactured products among themselves and in international markets. ${ }^{56}$ The state deregulated cooperative farms and permitted farmers to keep a larger proportion of the food they produced. ${ }^{57}$ Men were sometimes obliged to spend time at factories even if there was neither work nor wages for them, while women, who were less likely to be obliged to spend time at factories, began to engage in "sideline" production, selling home-cooked food or handicrafts. ${ }^{58}$ The state turned a blind eye to private markets that sprang up in urban areas, indeed legalizing them in 2002. ${ }^{59}$ The government also decided to change the pricing structure to reflect domestic real market conditions, aligning official prices more closely with black-market prices.

Economic reforms that introduced the basic elements of a market economy were absolutely necessary to put North Korea on the path to real self-sufficiency in food, in contrast to the official ideology of Juche that claimed to be a prescription for selfsufficiency. However, the reforms also had their own detrimental consequences. Although wages were increased, prices rose as well. ${ }^{60}$ Moreover, the reforms did not appear to cause a substantial increase in production, ${ }^{61}$ as farms and factories still lacked necessary inputs and fuel. ${ }^{62}$ As a result, North Korea faced the classic inflationary scenario of too much money facing too few goods-especially too little food.

By 2005, a new system of stratification between rich and poor had developed; those who had access to hard currency ${ }^{63}$ either through remittances (mostly from Japan or China), smuggling across the border with China, or crime (such as exporting arms or narcotics ${ }^{64}$ ) could buy what little food was in the market, while those dependent on meager state wages could not buy what they needed. Thus, this incomplete, regulated, "socialist" marketization resulted in high rates of post-famine malnutrition for those who could not find ways to earn hard currency. Moreover, in its attempt to marketize 
the economy, the government abolished the PDS in 2002 except for the top 1 or 2 million people in the country ${ }^{65}$ Those many other North Koreans who had relied on the PDS were suddenly forced to either cultivate their own food or buy food in markets; many lacked the resources to do either. About $50 \%$ of formerly PDS-dependent households were unable to meet their caloric requirements. ${ }^{66}$ Complicating matters even further, in 2005, the state overturned some of its reforms. It once again banned the private buying and selling of grain ${ }^{67}$ and reintroduced the PDS. ${ }^{68}$ As of 2008, markets were again closed and women under 40 were no longer allowed to trade, even though women were the mainstays of their families. ${ }^{69}$

Finally, a currency reform in late 2009 effectively wiped out the savings of those North Koreans who were managing to make money in private markets, which they had been using to purchase food. Citizens were obliged to turn in their banknotes, which were replaced at a rate of 1 per 100 wons. ${ }^{70}$ This was one of the few times that some parts of the population showed their displeasure, with demonstrations taking place against the regime. In response, the government executed Pak Nam Gi-the official in charge of the reform-and sent three dozen of his relatives to prison. ${ }^{71}$

Partly as a consequence of these incomplete and erratic reforms, severe food shortages causing malnutrition and death returned by the end of the decade. This food shortage was partly a result of a lack of seeds, fertilizer, fuel, storage capacity, and advanced agricultural technology. ${ }^{72}$ By 2008 , the country was "once again on the brink of starvation," with families eating grass, tree bark, and poisonous mushrooms that could cause death by diarrhea in young children.$^{73}$ Matters were made worse by periodic campaigns to boost industrial production, which removed farmers from their fields; "We are being led to our deaths," said one such farmer. ${ }^{74}$ These campaigns continued in 2010-2011 as preparations were made to celebrate the 100th anniversary of the birth of Kim Il Sung in 2012.

Rations in 2010 met less than half the daily food needs of the $68 \%$ of the population dependent upon them. ${ }^{75}$ In early 2011, North Korea was begging for food aid as a result of a hard winter, floods, and the spread of foot-and-mouth disease among its animals. ${ }^{76}$ In March 2011, estimates were that 6.1 million people-about a quarter of the population-were at severe risk of starvation, especially in the northern and eastern provinces. ${ }^{77}$ Diplomats reported that food rations had been halved in $2010-2011,{ }^{78}$ while "feral children" ate dead dogs and rotten food in the markets. ${ }^{79}$ By November 2011, a visiting UN official found that about a third of the children under five were at risk of long-term effects of malnutrition..$^{80}$ Even members of the military, normally favored by the regime, were suffering malnutrition. ${ }^{81}$

This short description of North Korean economic policy cannot explain all the decisions that caused famine in the 1990s and mass hunger, if not famine, again in 2010$2011 .^{82}$ In brief, until 2000, North Korea was a dogmatic, highly authoritarian state that refused to make even the mildest reforms. In the twenty-first century, reform was erratic and internally contradictory-in a word, incompetent at best. Thus, food shortages have been severe for two decades, reaching acute stages from 1994 to 2000 and again in 2010-2012.

\section{The Crime of Faminogenesis}

To determine how, if at all, Kim Jong Il should have been treated under international law, it is first necessary to assess in which category of faminogenesis his actions fell. Marcus's four categories are intentional, reckless, indifferent and incompetent 
faminogenesis; he argues that the first and second categories should be prohibited and punished. To reiterate, famine is intentional if the state deliberately uses it as a means of extermination; it is reckless if the state continues its food policies despite evidence of famine. North Korea's famines are at minimum reckless; over two decades the state continued policies that resulted in underproduction and maldistribution of food. The regime's consistent disregard for its citizens' food needs, its imprisonment of those committing "crimes" such as hoarding, and its suppression of those civil and political rights that might have permitted citizens to communicate their needs to the government also suggest intentional famine, though stronger evidence of mens rea than can be provided in this article may be required in a court of law to prove intentional famine.

Marcus argues that some of the North Korean government's actions during the 1990s famine constituted the first-degree crime of intentional faminogenesis. He accuses the government of "manipulating the famine to target certain populations that threaten its political survival" by denying them food rations. ${ }^{83}$ During the 1990s famine, "it was persistently reported that PDS rations were delayed or temporarily suspended in the northern parts of the country." ${ }^{4}$ However, Haggard and Noland state that they "find no evidence that particular segments of the population were deliberately starved." 85 They consider evidence demonstrating that the regime cut off four northern provinces to be circumstantial, although they note that there is evidence that the government focused food aid on the western coast, despite evidence that the (north) east coast was facing particularly severe food shortages. ${ }^{86}$

Haggard and Noland's view is that "informational failures and the lack of accountability characteristic of authoritarian regimes played a crucial role" in the famine. ${ }^{87}$ This suggests that the government was guilty of the second-degree crime of reckless faminogenesis, continuing policies that caused famine even when their consequences were known. Not permitting citizens to farm small plots of land was reckless; as such farms could have produced food to supplement official rations. Prohibition of trade and foraging was also reckless. In Marcus's view, "North Korea's behavior in refusing to admit that its policies are flawed . . constitutes a second-degree famine crime." 88 The same might be said of the famine of 2010-2012, which was caused in part by the regime's continuation of these extremely flawed policies. Recklessness is implied, for example, by the 2005 decision to rescind the reforms that had been implemented to assist in creating a market economy.

Incompetence, Marcus's fourth degree of faminogenesis, is the most generous description of a regime that followed policy prescriptions from the Soviet Union and China that had been abandoned by both countries by 1990 . On the other hand, the fact that North Korea sought food aid during the 1990s famine, and again in 2010-2012, suggests that the regime was not indifferent to the famine, thus not guilty of the third degree of faminogenesis. The regime did seek international help during the 1990s, asking South Korea, the UN, and the US for food aid.$^{89}$ However, there was some suspicion that the food was not disbursed to the neediest citizens; rather, it seemed that the military was well fed while others starved..$^{90}$ The regime may simply have treated food aid as balance-of-payments assistance: the less it spent on food, the more it had to pay off debts. ${ }^{91}$

Feffer claims the famine was not deliberate, but rather was a result of "atrocious policy." 92 Haggard and Noland also argue that "the famine was a classic case of state failure," ${ }^{\prime 93}$ rather than having been deliberately constructed. However, these arguments 
seem to inadvertently imply that the policies were made by honest bureaucrats who accidentally made poor decisions; they run contrary to Marcus's view that the government recklessly continued these policies even when their consequences became known. An alternate view is that the regime made decisions according to its own interests, regardless of the effects on some sectors of the population. As long as members of the Korean Workers' Party and the military-along with the relatively privileged inhabitants of the capital, Pyongyang-were fed, the regime could ignore its other citizens.

The regime also denied all human rights, so that citizens could not make their concerns known. Systematic denial of human rights during severe food shortages suggests at minimum reckless faminogenesis. The state deliberately denies itself a key resourcethe voices of its own people-that could help rectify its faminogenic policies. North Koreans enjoy no freedom of speech, assembly, or press; no political right to vote; and no civil rights to protection from torture or arbitrary execution. Citizens cannot protest the policies causing them to starve, nor can they vote their leaders out of office; if they do protest, they risk imprisonment, torture, and death. They cannot fulfill their need for food when they are not permitted freedom of movement to leave the country or even within it.

Moreover, North Koreans, enjoy no right to privacy whatsoever: neighbors are encouraged to spy on neighbors and all citizens must attend self-criticism sessions where they must confess and repent for even the tiniest acts that might be considered disloyal. Thus, independent thought and conversation are completely blocked by a system in which neighbors can and do report each other for "crimes" against the state such as foraging for, producing, and selling food, or even complaining about food shortages. Radios and televisions are wired so that they can receive only state channels ${ }^{94}$ which broadcast propaganda into every household, ${ }^{95}$ thus prohibiting the spread of information about food shortages that might cause unrest.

Another major policy "error" in North Korea is prohibition of private property. The right to own property is protected by Article 17 of the Universal Declaration of Human Rights (UDHR). This right helps individuals be self-sufficient rather than rely on the state to provide for all their needs. Aside from the micro-farms described above, no personal cultivation of land was permitted in North Korea until the $1990 \mathrm{~s}^{96}$ and there is still no private ownership of land. Even in the brief period of flowering markets during the early 2000s, no reforms were introduced to enable individuals to own the land they were farming. Yet individual land rights have been shown to result in "higher productivity, cultivation and yields, as well as the retention of surpluses against the risk of climatic disaster." ${ }^{\prime 7}$

All these denials of citizens' human rights are consequences of deliberate policy decisions. A government concerned with the welfare of its citizens would not continue policies that cause its citizens to starve. Thus, the regime is recklessly faminogenic, prohibiting human rights that could avert or alleviate famine. It is not quite as easy to make a case for intentional faminogenesis, especially given the inconsistent and erratic "reforms" the state introduced after the mid-1990s. In either case, though, denial of citizens' civil and political rights is a key cause of the starvation. Not enjoying any of these rights, North Koreans resort to occasional protests, strikes, uprisings, sabotage, and even murders of local officials. ${ }^{98}$ There have also been reports of attempted assassinations and coups d'état, suggesting dissension within the ruling clique and/or the military. ${ }^{99}$ 


\section{The Crime of Penal Starvation}

The North Korean regime is responsible not only for famine, but also for a deliberate policy of subjecting its prisoners to starvation rations. The government maintains a large system of repressive slave labor camps-in effect, a gulag-in which prisoners are even more likely to starve than the general population. Rations are far below what is needed to maintain health and were so even before the food shortages and famine of the 1990s: "Prisoners are provided only enough food to be kept perpetually on the verge of starvation." 100 Food is allocated on the basis of productivity: the less a prisoner produces, the less he eats, resulting in a spiral downward as those deprived of even more food produce less and less. Many in the camps die from lack of food, while some are executed for foraging; in one case a prisoner was executed for eating ripe chestnuts that had fallen at the entrance of a slave labor mine. ${ }^{101}$

I use the term penal starvation to describe this phenomenon. Penal starvation does not cause death in the manner to which Sen refers, in which malnutrition spreads over wide populations. Rather, it attacks a significant percentage of prisoners who cannot live on rations constantly below subsistence level, or whose food rations are even lower than the prescribed below-subsistence level because they do not work hard enough or have angered the authorities in some other way. Estimates of how many people are in the prison camps at any time vary, but most sources agree on about 200,000 every year. ${ }^{102}$ Pierre Rigoulot, publishing originally in 1997, estimated that 1.5 million people had died in the camps since the creation of North Korea. ${ }^{103}$ Becker's lower estimate suggested that as of 2005,1 million people had died, assuming an annual death rate of $10 \%$ of prisoners. ${ }^{104}$

Inmates in these camps fall into two major groups. The first is people who have been imprisoned for political reasons or because they belong to population categories that the regime considers disloyal or dangerous. Over the course of North Korea's history, tens of thousands of people have been imprisoned in various political purges. ${ }^{105}$ The state also classifies every individual citizen on the basis of perceived loyalty, or lack thereof, to the regime: the three classes are the core, or loyal, class; the wavering class; and the hostile class. South Korea estimates that these categories constitute 30, 50, and $20 \%$ of the population respectively. ${ }^{106}$ Membership in the three core classes is hereditary; for example, an individual might be deemed a member of the hostile class if his greatgrandfather was a landlord. Members of the hostile class are most likely to be sent to the gulag; they were also the first to have their rations cut during the 1990s famine. ${ }^{107}$

Some other categories of people are so despised that they are frequently sent to prison camps where they suffer a high risk of starvation. In the past, North Korea imprisoned Japanese-Koreans; that is, Koreans who had lived in Japan when Korea was under Japanese colonial rule, but had been badly treated there. Some of the estimated 93,000 returnees from Japan were incarcerated. ${ }^{108}$ Christians are also imprisoned or executed; ${ }^{109}$ the earliest massacre of Christians appears to have taken place in November $1945,{ }^{110}$ and it is believed that the government executed about 400,000 religious practitioners (not all Christians) during the 1970s. ${ }^{111}$ In the past, moreover, disabled people were sent to special concentration camps in accordance with the Kims' (father and son) belief that North Koreans ought to be physically perfect. ${ }^{112}$ The Kims had a particular aversion to dwarfs, who along with other disabled people were exiled from the capital. ${ }^{113}$ Dwarfs were put in special prison camps and subjected to forced sterilization. It appears, however, that in the last two decades disabled people have been somewhat better treated and are less likely to be imprisoned. ${ }^{114}$ 
Not only those convicted of crimes, but also their families, including parents, spouses, siblings, and children, are imprisoned. This is in accordance with Kim Il Sung's 1958 directive that "[prison] inmates are class enemies and must be actively exterminated to three generations," 115 which was apparently repeated in 1972: "Factionalists or enemies of class, whoever they are: their seed must be eliminated through three generations." 116 Thus, for example, Kang Chol-Hwan, author of a rare memoir of the camps, was incarcerated at the age of nine because his grandfather was suspected of a crime; Kang survived partly by eating rats. ${ }^{117}$ This form of collective punishment is one reason why the gulag contains so many prisoners.

The second group of prisoners is made up of people whose actions in search of food are considered illegal. Their crimes consist of engaging in petty trade, cultivating small plots of land, hoarding food, ${ }^{118}$ foraging, traveling within the country in search of food, ${ }^{119}$ stealing food, smuggling and other black market activities, and cannibalism. It is estimated that about $200-300,000$ people fled to China during the 1990 s famine: ${ }^{120}$ China returns refugees to North Korea, where most are then imprisoned and "restarved." Having committed what the state considers to be crimes in order to survive the famine, they are incarcerated and deliberately subjected to starvation rations. It is not yet known, however, whether North Korea engaged in the same policy of incarcerating people who were trying to find food in 2010-2012 as it did during the 1990s.

Applying Marcus's four categories of intentional, reckless, indifferent, and incompetent famine to penal starvation, it appears clear that penal starvation is intentional. The state decides whom to imprison, it decides on food rations for prisoners, and it decides that prisoners can be deprived of food for various further transgressions while in prison, such as not working hard enough. Thus, as a subset of faminogenesis, penal starvation should be punished as a first-degree famine crime, although again, a court of law might require stronger proof of mens rea that I can supply here.

\section{International Law: The Question of Genocide}

If famine in North Korea is at minimum reckless and possibly intentional, and if penal starvation is clearly intentional, then how, if at all, can international law stop these two practices? One possibility is to pressure North Korea to live up to its formal commitments to uphold those human rights covenants to which it is party. North Korea became party to both the International Covenant on Economic, Social and Cultural Rights (ICESCR) and the International Covenant on Civil and Political Rights (ICCPR) on 14 September 1981. The ICESCR includes the right to adequate food (article 11[1]) and freedom from hunger (article 11[2]). But as discussed above, this right cannot stand alone: in order to have access to enough food, citizens must also enjoy their civil and political rights.

It is unlikely, however, that the North Korean regime will be susceptible to pressure to protect human rights. In a facade of legality, the regime has introduced constitutional changes that are supposed to-but do not-protect human rights on several occasions. In 1998, a constitutional revision introduced habeas corpus and revisions in 2004 prohibited arrests and detention not in accordance with the law, required warrants for arrests, and introduced other such procedural guarantees. ${ }^{121}$ In 2009 , the constitution was revised ostensibly to protect human rights. ${ }^{122}$ For example, articles $65-68$ protected equal rights; the right to vote; freedom of speech, press, assembly, demonstration, and association; and freedom of religion. ${ }^{123}$ At the same time, however, the principle of "military first" was included, allocating resources to the military before any other sector 
of society. ${ }^{124}$ There is no indication that North Korea now respects the rights written into the 2009 constitution.

Since the regime is unlikely to protect human rights, the possibility of punishing its leaders must be considered. It is possible that Kim Jong Il could have been referred to the International Criminal Court (ICC) for the crime of genocide before his death in December 2011. In 1996, Kim apparently said that North Korea only needed $30 \%$ of its populace to survive in order to reconstruct a "victorious" North Korean society, suggesting a very high tolerance for mass deaths among those for whom he was supposed to be responsible. ${ }^{125}$

The United Nations Convention on the Prevention and Punishment of the Crime of Genocide (UNCG) is meant to protect groups at risk of genocide because of their race, religion, ethnicity, or nationality. ${ }^{126}$ Certain groups that fit these categories have been targeted for extermination in North Korea. North Korean Christians are one such group, as adherence to Christianity is viewed as treason against the Juche philosophy and the Kim dynasty. A second group is Japanese-Koreans, whose situation has been described above. A third is Korean-Chinese infants, ${ }^{127}$ who are considered to be "polluting" the pure Korean race. These infants are the children of North Korean mothers who fled or were trafficked to China, where they sometimes voluntarily married and sometimes were forcibly married or prostituted to Chinese men. In violation of its obligations under the United Nations Convention Relating to the Status of Refugees (CRSR), as discussed below, China returns refugees to North Korea. Eyewitnesses have recounted that if these women are pregnant when they return, they are made to undergo forced abortions. If they are in the late stages of pregnancy, delivery is induced and the infants are then murdered or tossed alive into garbage cans before their mothers' eyes. ${ }^{128}$ This can be considered "ethnic infanticide," which constitutes "killing of members of a group." 129

While the particular cases of Christians, Japanese-Koreans, and Chinese-Korean infants may fit the UNCG definition of victim groups, the majority of people subjected to state-induced famine or penal starvation do not fit this definition. Rather, the North Korean regime commits politicide, defining "victim groups ... in terms of their political status or opposition to the state." 130 The famine of the 1990s and the continuing risk of starvation in the twenty-first century affects all North Koreans except the core, inner elite; even members of the military and of the Korean Workers' Party are at risk. Moreover, disproportionate incarceration of members of the hostile class might be considered a form of politicide; certain categories of people deemed to be politically unreliable are at substantially increased risk of penal starvation. Frank Chalk and Kurt Jonassohn's definition of genocide applies to North Korea: "Genocide is a form of one-sided mass killing [for example, by state-induced famine and penal starvation] in which a state or other authority intends to destroy a group, as that group and membership in it are defined by the perpetrator." 131 The perpetrator-the North Korean regime-defines some citizens as hostile and starves them accordingly.

Even if some of North Korea's famine victims fit the UNCG's definition of victim groups, however, the crime of faminogenesis is not specified in the UNCG. Yet both the intentional and the reckless varieties of state-induced famine cause serious bodily harm to members of a group and also inflict "conditions of life calculated to bring about [a group's] physical destruction in whole or in part," thus fulfilling aspects of genocide as defined in article 2 (b) and (c) of the UNCG. ${ }^{132}$ State-induced famine also prevents 
births within a group, a practice prohibited by Article 2 (d), as starving women are not capable of conception. The group, in this case, is made up of all North Korean citizens.

A further difficulty in proving a charge of genocide against Kim Jong Il is the question of intent. Did Kim intend to kill 3-5\% of North Korea's citizens, or was he merely reckless in continuing his economic policies even when it was obvious that they caused starvation? Jasper Becker, a journalist, contends that "the most heinous part of the story is that the leadership, especially Kim Jong Il, resisted adopting every policy that could have brought the misery [of the 1990s] to a quick end. This makes the suffering he inflicted on an entire people an unparalleled and monstrous crime." 133 Paul French agrees, noting, "At no time did the state admit to any ideological, economic, or systemic problems as causes of the ... famine."134 Indeed, it might seem that resistance to economic reform, combined with complete denial of all civil and political rights; diversion of food aid to support the Korean Workers' Party, the military, and the elite; and discrimination against some provinces in provision of food, add up to evidence of intent. Nevertheless, none of these elements provides the "smoking gun" proving that Kim wanted to kill his own population, and his frequent appeals for international food aid suggest the contrary.

A further gap in international law is the absence of a specific crime of penal starvation. The United Nations Committee on Economic, Social and Cultural Rights has ruled that whenever individuals or groups are unable to enjoy the right to adequate food via their own means, the state has the obligation to directly fulfill that right. ${ }^{135}$ The United Nations' Standard Minimum Rules for the Treatment of Prisoners specify that "every prisoner shall be provided ... with food of nutritional value adequate for health and strength." 136 These rules can be read to protect not only "normal," individual prisoners, but also large groups of people deliberately incarcerated and subjected to rations below the subsistence level. This positive obligation to provide food, however, fails to penalize states that deliberately starve large numbers of prisoners as a matter of policy or of common-and encouraged-practice. Nor is penal starvation specified as an act of cruel, inhuman or degrading punishment in the Convention against Torture, ${ }^{137}$ although it is obviously extremely cruel and degrading to force individuals to beg, scrounge, smuggle, steal, kill, and even become cannibals in their search for food.

Even if referral to the ICC for genocide was not possible, a strong case could have been made that Kim Jong Il was guilty of almost all the crimes against humanity the ICC prohibits, including murder, torture, deportations, enslavement, and persecution. ${ }^{138}$ There is no specific mention of state-induced famine or penal starvation in the list of crimes against humanity; rather, it seems these two crimes would qualify merely as "other inhumane act $[\mathrm{s}]$... intentionally causing great suffering, or serious injury to body or to mental or physical health." ${ }^{139}$ Grace Kang argues that food deprivation in prison camps can be considered acts of murder or extermination, reinforcing the argument that Kim Jong Il should have been referred to the ICC. ${ }^{140}$ Similarly, Debra LiangFenton argues that "the North Korean government is actively involved in committing crimes against humanity with respect to both its food policy leading to famine and its treatment of political prisoners;" these are crimes against humanity because the government knowingly engages in policies that cause hunger and starvation. ${ }^{141}$

In October 2011, a coalition of human rights groups launched a campaign in Tokyo to have the United Nations establish a commission of inquiry into crimes against humanity in North Korea. ${ }^{142}$ As of the time of writing (August 2012), however, North 
Korea was not party to the ICC; thus, were he still alive, Kim Jong Il would have to be referred to the court by the United Nations Security Council (UNSC). Such referral either of him or of his successor, Kim Jong Un, was and is unlikely, as North Korea has been testing nuclear weapons and the geostrategic concern to contain its nuclear ambitions tops the international community's agenda, as discussed further below. North Korea has, however, been referred to the ICC by South Korea for a possible war crime. In March 2010, a South Korean ship, the Cheonan, sank, resulting in the loss of 46 lives. An international commission determined that a North Korean torpedo had struck it and in December 2010 the ICC opened a preliminary investigation into whether the sinking of the Cheonan was a war crime. ${ }^{143}$ This suggests some willingness on the part of the international community to refer North Korea to the ICC while concurrently trying to negotiate with the regime to curb its development of nuclear weapons.

Another aspect of international law that might be useful in protecting North Koreans is refugee law. It is estimated that by 2009 , between 100,000 and 300,000 North Koreans were living in China. ${ }^{144}$ China has been party to the UN Convention on Refugees since 1982; thus, it is obligated to protect refugees fleeing North Korea because of political or religious persecution. This entails setting up a refugee adjudication process and allowing the UN High Commissioner for Refugees access to North Koreans in China. ${ }^{145}$ China also should protect refugees who have had contact with South Koreans, missionaries, or aid workers, as they are likely to be punished more harshly than other returnees should they be sent back to North Korea; people who went to church in China, for example, are sentenced to ten years in prison camps. ${ }^{146}$ China is also obligated to protect those many female refugees-both women and girls-who end up working in the sex trade ${ }^{147}$ and to make sure that they are not persecuted if they are returned to North Korea.

Yet China signed an agreement with North Korea in 1986 to return refugees, ${ }^{148}$ sending back about $10 \%$ of them every year. ${ }^{149}$ The agreement permits North Korean agents to operate in northern China to intimidate, abduct, and murder refugees. ${ }^{150} \mathrm{It}$ also imposes arrest quotas on Chinese border police, ${ }^{151}$ fines anyone helping refugees a substantial sum, ${ }^{152}$ and offers a reward of $\$ 500$ to any Chinese citizen who turns in a North Korean refugee. ${ }^{153}$

In general, China does not consider starving North Koreans to be political refugees, as if they were fleeing a natural, rather than a politically-designed, food disaster; the Chinese government claims they are economic migrants. ${ }^{154}$ Yet they are actually political refugees, in the sense that they are fleeing state policies that prevent them from eating. Moreover, the government's discriminatory distribution of food-for example, by denying food to members of the hostile class-constitutes political persecution. ${ }^{155}$ At the moment, refugee activists are limited to the argument that even if North Koreans are not political refugees when they enter China, they become political refugees sur place when threatened with the torture, imprisonment, starvation, and execution that follow refugees' return to North Korea. ${ }^{156}$ In 2008, 13 women and two men were executed merely for planning to go to China. ${ }^{157}$ To avoid such repatriations and to incorporate both faminogenesis and penal starvation into refugee law, state-induced famine should be considered a crime against humanity—if not a form of genocide-and people fleeing this crime should be considered refugees.

Despite the laws against genocide and crimes against humanity, and the laws that ostensibly protect refugees, the international community takes relatively tentative 
actions against North Korea. Strategic and security interests trump concern for human rights.

\section{Conclusion: Strategic vs. Humanitarian Concerns}

Marcus argues that aspects of intentional and reckless faminogenesis are already crimes under various international laws, but that all these laws should be brought together in a single UN convention. ${ }^{158} \mathrm{Had}$ such a convention existed, it might have been possible to indict Kim Jong Il before the ICC without having to prove that his crimes were directed against a "national, ethnical, racial or religious group as such," as required by the UNCG. Such a convention might also have prohibited penal starvation as a specific sub-category of the crime of faminogenesis. In the absence of such an agreement, Kim Jong Il should have been prosecuted for the many crimes against humanity and genocidal acts of which he was guilty. Some of Kim's close associates were still in power in 2012 and remained candidates for prosecution, as will be his son and successor, Kim Jong Un, if he does not change North Korea's food production and distribution policies and does not immediately ensure that prisoners are properly fed.

But such prosecution is unlikely. The international community's chief concern regarding North Korea is strategic, not humanitarian. North Korea has been developing nuclear weapons since the 1980s and already possesses illegal chemical and biological weapons. ${ }^{159}$ Six-party talks among the two Koreas, the United States, Japan, China, and Russia have been taking place sporadically since 2003 with the objective of controlling North Korea's nuclear ambitions. Food aid, along with other types of aid, is sometimes used as an incentive to persuade North Korea to take part in these talks, and conversely is sometimes withdrawn or cut if North Korea refuses to cooperate. ${ }^{160}$

The US is particularly concerned by North Korea's nuclear aspirations and has had sanctions against North Korea for some years, partly for the purpose of choking off the flow of luxury goods into elites' hands. North Korea finances its purchases of these goods by exporting drugs such as opium and heroin and by counterfeiting US currency. ${ }^{161}$ China, on the other hand, has an ambiguous relationship with North Korea. Like the US, it fears nuclear weapons, but it has also been investing in North Korea and is interested in more bilateral trade. Moreover, China also fears a much larger outflow of refugees from North Korea into its northern region than currently exists, should the North Korean regime collapse.

South Korea is interested in preserving a stable North Korea. Its official ideology is that the two Koreas will someday unite, but, in fact, it also fears a refugee overflow ${ }^{162}$ and is wary of the very severe costs of reunification, were it ever to occur: one estimate has put the amount at $\$ 900$ billion over four decades. ${ }^{163}$ Finally, South Korea has a very real fear of attack by North Korea, which already possesses conventional weapons that could wipe out its capital, Seoul. ${ }^{164}$ It must therefore balance its concern for its starving co-ethnics with the need to avert attacks and to protect its own economy.

Thus, it appears that the international community, the US, China, and South Korea all agree that their first strategic priority is a stable North Korea that does not develop or use nuclear weapons. It is extremely doubtful that either China or Russia would support referral of North Korea's leaders to the ICC by the UNSC; even the US might argue that such an indictment would stand in the way of the six-party negotiations. No state or international organization has invoked the evolving principle of the responsibility to protect with regard to North Korea. ${ }^{165}$ The preferred option appears to be to simply wait for change. News of the prosperity of China and South Korea filters into 
North Korea via returned refugees and via traders who smuggled videos and DVDs in from China. ${ }^{166}$ The more North Koreans encounter goods from the global marketplace and visitors from the rest of the world, the harder it is for the regime to trumpet its nonsensical propaganda about being the best country in the world. ${ }^{167}$

However, since Kim Jong Il's death the principal concern of the international community has been to preserve North Korea's internal stability and avert further nuclear development. Factional infighting among members of the military or civilian elites could result in a collapsed or failed state, causing massive refugee outflows into China and South Korea, civil war, and the need for United Nations peacekeeping or peacemaking troops. Such infighting might also trigger actual use of nuclear weapons by one faction. As long as nuclear threat and internal stability are the international community's chief concerns, the crimes of faminogenesis and penal starvation will likely remain overlooked.

\section{Acknowledgements}

I am most grateful to Kwan-Sen Wen and Elizabeth Baisley for their research assistance and to my anonymous reviewers for their extremely helpful comments. I also thank the Canada Research Chairs program for the time and funds necessary to write this article, and Wilfrid Laurier University for nominating me for my Chair.

Rhoda E. Howard-Hassmann is Canada Research Chair in International Human Rights at Wilfrid Laurier University. She is also a Fellow of the Royal Society of Canada. Her current research is on governments that starve their own citizens: so far, her case studies include Zimbabwe and North Korea.

\section{Notes}

1. Amartya Sen, Poverty and Famines: An Essay on Entitlement and Deprivation (Oxford: Clarendon, 1981), 40.

2. David Marcus, "Famine Crimes in International Law," American Journal of International Law 97 (2003): 246-7.

3. Timothy Snyder, Bloodlands: Europe between Hitler and Stalin (New York: Basic Books, 2010), 53.

4. Frank Dikötter, Mao's Great Famine: The History of China's Most Devastating Catastrophe, 1958-1962 (New York: Walker \& Co., 2010), x.

5. Snyder, Bloodlands, 380.

6. Anne Applebaum, Gulag: A History (New York: Random House, 2003).

7. Jean-Louis Margolin, "China: A Long March into Night," in The Black Book of Communism: Crimes, Terror, Repression, ed. S. Courtois et al., (Cambridge, MA: Harvard UP, 1999), 503.

8. Amartya Sen, Development as Freedom (New York: Alfred A. Knopf, 1999), 178.

9. Andrew S. Natsios, The Great North Korean Famine: Famine, Politics, and Foreign Policy (Washington, DC: US Institute of Peace, 2001), xix.

10. Stephan Haggard and Marcus Noland, Repression and Punishment in North Korea: Survey Evidence of Prison Camp Experiences (Honolulu: East-West Center, 2009).

11. Kyung Moon Hwang, A History of Korea: An Episodic Narrative (New York: Palgrave Macmillan, 2010), 185.

12. Hwang, Episodic Narrative, 210.

13. Christoph Bluth, Korea (Cambridge, UK: Polity, 2008), 22.

14. Pierre Rigoulot, "Crimes, Terror, and Secrecy in North Korea," in Courtois, Black Book, 548.

15. Ibid., 559.

16. Ralph Hassig and Kongdan Oh, The Hidden People of North Korea: Everyday Life in the Hermit Kingdom (New York: Rowman and Littlefield, 2009), 33.

17. Bluth, Korea, 25.

18. International Institute for Strategic Studies, The Military Balance 2010 (London: International Institute for Strategic Studies, 2011), 412.

19. Bluth, Korea, 32-4.

20. Hassig and Oh, Hidden People, 69. 
21. Paul French, North Korea: the Paranoid Peninsula; A Modern History (New York: Zed, 2007$), 76$.

22. Stephan Haggard and Marcus Noland, Famine in North Korea: Markets, Aid, and Reform (New York: Columbia UP, 2007), 9.

23. John Feffer, "North Korea and the Politics of Famine," in Foreign Policy in Focus Special Report (Washington, DC: Foreign Policy in Focus, 2006), 5.

24. French, Paranoid Peninsula, 73-114.

25. Ibid., 117.

26. Ibid., 119.

27. Marcus Noland, Sherman Robinson, and Tao Wang, "Famine in North Korea: Causes and Cures," Economic Development and Cultural Change 49 (2007): 747.

28. Natsios, Great North Korean Famine, 10.

29. Ibid., 21.

30. See, for example, Jasper Becker, Rogue Regime: Kim Jong Il and the Looming Threat of North Korea (New York: Oxford UP, 2005), 211.

31. Daniel Goodkind and Loraine West, "The North Korean Famine and its Demographic Impact," Population and Development Review 27 (2001): 220; Haggard and Noland, Famine in North Korea, 1.

32. Suk Lee, The DPRK Famine of 1994-2000: Existence and Impact (Seoul: Korea Institute for National Unification, 2005), 47.

33. Marcus Noland, "North Korea as a 'New' Famine," in The New Famines: Why Famines Persist in an Era of Globalization, ed. S. Devereux (New York: Routledge, 2007), 201.

34. Goodkind and West, "North Korean Famine," 221.

35. Lee, DPRK Famine, 35.

36. Bluth, Korea, 38.

37. Natsios, Great North Korean Famine, 5.

38. Marcus, "Famine Crimes in International Law," 260.

39. B.R. Myers, The Cleanest Race: How North Koreans See Themselves-And Why It Matters (Brooklyn: Melville House, 2010), 118.

40. Marcus, "Famine Crimes in International Law," 260.

41. Natsios, Great North Korean Famine, 109.

42. Noland, Robinson, and Wang, "Famine in North Korea," 747.

43. Barbara Demick, Nothing to Envy: Ordinary Lives in North Korea (New York: Spiegel and Grau, 2009), 113.

44. Ibid., 167.

45. Becker, Rogue Regime, 29.

46. Demick, Nothing to Envy, 153.

47. Ibid., 168 .

48. Mike Kim, Escaping North Korea: Defiance and Hope in the World's Most Repressive Country (New York: Rowman and Littlefield, 2008), 50.

49. French, Paranoid Peninsula, 130.

50. Demick, Nothing to Envy, 195.

51. Lee, DPRK Famine, 13.

52. Kim, Escaping North Korea, 51.

53. Demick, Nothing to Envy, 188.

54. Haggard and Noland, Markets, Aid, and Reform, 2.

55. Lee, DPRK Famine, 6.

56. Bluth, Korea, 41.

57. Lee, DPRK Famine, 13.

58. Park Kyung-Ae, "Gender Security in North Korea" (paper presented at the annual meeting of the International Studies Association, Montreal, Canada, 18 March 2011), 8.

59. Bluth, Korea, 41; Christian Caryl, “The Other North Korea," New York Review of Books 55,13 (2008): 26.

60. “North Korea: Through a Glass, Darkly," Economist, 13 March 2004, 41-3.

61. Hassig and Oh, Hidden People, 103.

62. "The Odd Couple: A Special Report on the Koreas," Economist, 27 September 2008, 14.

63. Hassig and Oh, Hidden People, 130.

64. French, Paranoid Peninsula, 99.

65. Hassig and Oh, Hidden People, 114.

66. French, Paranoid Peninsula, 143.

67. Feffer, "Politics of Famine," 17. 
68. Human Rights Watch, A Matter of Survival: The North Korean Government's Control of Food and the Risk of Hunger (New York: Human Rights Watch, 2006), 2-3.

69. "Mad, Bad and Dangerous to Know," Economist, 16 January 2010, 45; Park, "Gender Security."

70. “No Wonder: North Korea’s Currency Grab,” Economist, 5 December 2009, 52.

71. “Aid group: NKorea Jailed Kin of Currency Reformer," China Post, 7 July 2010.

72. Human Rights Watch, World Report 2010: Events of 2009 (New York: Human Rights Watch, 2010).

73. "Starving North Koreans Forced to Survive on Diet of Grass and Tree Bark," Amnesty International, 15 July 2010, http://www.amnesty.org/en/news-and-updates/starving-north-koreans-forced-survive-dietgrass-and-tree-bark-2010-07-14 (accessed 1 Aug 2012); “North Korea: Let Them Eat Juche,” Economist, 10 May 2008, 50.

74. "Hell on Earth," Economist, 24 October 2009, 56.

75. World Food Programme, Korea, Democratic People's Republic (DPRK) (World Food Programme, 2010).

76. Chico Harlan, "Starving N. Korea Begs for Food, but US Has Concerns about Resuming Aid," Washington Post, 22 February 2011.

77. World Food Programme, Food and Agriculture Organization, and UNICEF, WFP/FAO/UNICEF Rapid Food Security Assessment Mission to the Democratic People's Republic of Korea (World Food Programme, 2011), 29.

78. Gerald Bourke, "North Korea Slashes Food Rations: Aid Worker," Agence France-Presse, 28 June 2011.

79. “Deprive and Rule," Economist, 17 September 2011, 42.

80. John J. Metzler, “UN Mission to North Korea," Korea Times, 6 November 2011.

81. Julian Ryall, "Half of North Korea's Army 'Starving," Telegraph, 13 September 2011.

82. For a detailed description of North Korean economic policies, see French, Paranoid Peninsula, 73-182.

83. Marcus, "Famine Crimes in International Law," 260.

84. Lee, DPRK Famine, 7.

85. Haggard and Noland, Markets, Aid, and Reform, 10.

86. Ibid., 64-5.

87. Ibid., 10 .

88. Marcus, "Famine Crimes in International Law," 260.

89. Lee, DPRK Famine, 2.

90. Rigoulot, "Crimes, Terror, and Secrecy," 563.

91. Debra Liang-Fenton, "Failing to Protect: Food Shortages and Prison Camps in North Korea," Asian Perspective 31 (2007): 52.

92. Feffer, "Politics of Famine," 6.

93. Haggard and Noland, Repression and Punishment, 1.

94. Human Rights Watch, Matter of Survival, 6.

95. Christian Caryl, "North Korea: The Crisis of Faith," New York Review of Books 57,12 (2010): 30.

96. Demick, Nothing to Envy, 33.

97. French, Paranoid Peninsula, 136.

98. Becker, Rogue Regime, 36.

99. Bluth, Korea, 31.

100. David Hawk, The Hidden Gulag: Exposing North Korea's Prison Camps (Washington, DC: US Committee for Human Rights in North Korea, 2003), 25.

101. Ibid., 37.

102. Human Rights Watch, World Report 2011: Events of 2010 (New York: Human Rights Watch, 2011), 345.

103. Rigoulot, "Crimes, Terror, and Secrecy," 564.

104. Becker, Rogue Regime, 87.

105. Hassig and Oh, Hidden People, 208.

106. Ibid., 198.

107. Ibid., 203.

108. Ibid., 208.

109. Patricia Goedde, "Legal Mobilization for Human Rights Protection in North Korea: Furthering Discourse or Discord?," Human Rights Quarterly 32 (2010): 554; Hawk, Hidden Gulag, 67.

110. Hwang, Episodic Narrative, 216.

111. Human Rights Watch, North Korea: Harsher Policies against Border Crossings (New York: Human Rights Watch, 2007), 7.

112. Myers, Cleanest Race.

113. Natsios, Great North Korean Famine, 37. 
114. Park Young-ho et al., White Paper on Human Rights in North Korea (Seoul: Korea Institute for National Unification, 2010).

115. Becker, Rogue Regime, 90.

116. Robert Park, "North Korea and the Genocide Movement," ISG [Institute for the Study of Genocide] Newsletter 46 (2011): 11.

117. Kang Chol-Hwan, "The Aquariums of Pyongyang," in From the Gulag to the Killing Fields: Personal Accounts of Political Violence and Repression in Communist States, ed. P. Hollander (Wilmington, DE: ISI Books, 2006), 688.

118. French, Paranoid Peninsula, 144.

119. William J. Moon, "The Origins of the Great North Korean Famine: Its Dynamics and Normative Implications," North Korean Review 5 (2009): 112.

120. Hawk, Hidden Gulag, 56.

121. Haggard and Noland, Repression and Punishment, 17.

122. Jiyoung Song, “The Right to Survival in the Democratic People's Republic of Korea," European Journal of East Asian Studies 9 (2010): 113.

123. Democratic People's Republic of Korea, North Korea Constitution, trans. Steve S. Sin (Pyongyang: Democratic People's Republic of Korea, 2009).

124. Song, "Right to Survival," 93.

125. Fiona Terry, "Feeding the Dictator: Food Aid to North Korea Only Props up Kim Jong-il's Grotesque Regime; It Should Be Stopped," Guardian, 6 August 2001.

126. Convention on the Prevention and Punishment of the Crime of Genocide, 9 Dec 1948, http://www2. ohchr.org/english/law/genocide.htm, art. 2.

127. Goedde, "Legal Mobilization," 554.

128. Stephan Haggard and Marcus Noland, Witness to Transformation: Refugee Insights into North Korea (Washington, DC: Peterson Institute for International Economics, 2011), 97; Hawk, Hidden Gulag, 61-2.

129. Park, "North Korea and the Genocide Movement," 11.

130. Barbara Harff and Ted Robert Gurr, "Toward Empirical Theory of Genocides and Politicides: Identification and Measurement of Cases since 1945," International Studies Quarterly 32 (1988): 359.

131. Frank Chalk and Kurt Jonassohn, The History and Sociology of Genocide: Analyses and Case Studies (New Haven: Yale UP, 1990), 23.

132. Convention on the Prevention and Punishment of the Crime of Genocide, 9 Dec 1948, http://www2. ohchr.org/english/law/genocide.htm.

133. Becker, Rogue Regime, 31.

134. French, Paranoid Peninsula, 116.

135. Human Rights Watch, Harsher Policies, 10.

136. Standard Minimum Rules for the Treatment of Prisoners, United Nations Economic and Social Council Resolution 2076, http://www2.ohchr.org/english/law/treatmentprisoners.htm (13 May 1977), art. 20.

137. Convention against Torture and Other Cruel, Inhuman or Degrading Treatment or Punishment, United Nations General Assembly Resolution 39/46, 10 December 1984, http://www2.ohchr.org/english/law/ cat.htm.

138. Goedde, "Legal Mobilization," 554; Grace M. Kang, "A Case for the Prosecution of Kim Jong Il for Crimes against Humanity, Genocide, and War Crimes," Columbia Human Rights Law Review 38 (2006).

139. Rome Statute of the International Criminal Court, U.N. Doc. A/CONF.183/9 (17 July 1998), art. 7(1) (k).

140. Kang, "Prosecution of Kim Jong Il," 79-80.

141. Liang-Fenton, "Failing to Protect," 69.

142. Ivana Kvesic, "North Korea: Human Rights Coalition Sends Letter to Kim Jong Il Urging Access," Christian Post, 5 October 2011.

143. International Criminal Court, ICC Prosecutor: Alleged war crimes in the territory of the Republic of Korea under preliminary examination (Office of the Prosecutor: International Criminal Court, 2010).

144. Park Kyung-Ae, "People's Exit in North Korea: New Threat to Regime Stability?," Pacific Focus 25 (2010): 262.

145. Roberta Cohen, Legal Grounds for Protection of North Korean Refugees (Washington, DC: Brookings Institution, 2010).

146. Human Rights Watch, Harsher Policies, 7.

147. For a description of what happened to two such women, see Tim O'Neill, "Escape from North Korea," National Geographic 215 (2009). 
148. Goedde, "Legal Mobilization," 557.

149. Park, "People's Exit," 260.

150. Becker, Rogue Regime, 27.

151. Ibid., 38.

152. Ibid., 23.

153. Park, "People's Exit," 273.

154. Elim Chan and Andreas Schloenhardt, "North Korean Refugees and International Refugee Law," International Journal of Refugee Law 19 (2007): 224.

155. Ibid., 230.

156. Cohen, Legal Grounds.

157. "Let Them Eat Juche," Economist.

158. Marcus, "Famine Crimes in International Law," 261-81.

159. "Odd Couple," Economist, 16.

160. French, Paranoid Peninsula, 185-215.

161. Mark Landler, "New US Sanctions Aim at North Korean Elite," New York Times, 30 August 2010.

162. Richard Bernstein, "How Not to Deal with North Korea," New York Review of Books 54,3 (2007): 39.

163. "Not Waving. Perhaps drowning," Economist, 29 May 2010, 25.

164. Bernstein, "How Not to Deal," 38.

165. International Commission on Intervention and State Sovereignty, The Responsibility to Protect (Ottawa: International Development Research Centre, 2001).

166. Caryl, “The Other North Korea," 26.

167. Nicholas Kristof, "North Korea’s Secret," New York Times, 14 January 2003. 